\title{
PERBEDAAN NILAI SKELETAL DALAM ARAH VERTIKAL ANTARA POLA PERNAFASAN NORMAL DAN PERNAFASAN MELALUI MULUT PADA PASIEN DI KLINIK ORTODONTI RSGMP FKG USU TAHUN 2009-2013
}

\author{
(THE DIFFERENCES OF SKELETAL VERTICAL MEASUREMENTS BETWEEN \\ NORMAL RESPIRATORY AND MOUTH BREATHING PATTERNS IN \\ PATIENTS AT ORTHODONTICS CLINIC \\ RSGMP FKG USU IN 2009-2013)
}

Hilda Fitria Lubis, Aida Violiny

Departemen Ortodonsia

Fakultas Kedokteran Gigi, Universitas Sumatera Utara

Jl. Alumni No. 2 Kampus USU Medan 20155

\begin{abstract}
Respiratory patterns associated with growth and development of dentocraniofacial. The switch repiratory pattern from nasal to mouth has been believed as one of etiological factors including excessive vertical growth. The aim of this study was to evaluate the differences of vertical skeletal measurements between normal respiratory and mouth breathing patterns in patients at orthodontics clinic RSGMP FKG USU in 2009-2013. This study consisted of 44 cephalometric radiographs from patients aged 8-12 years old with maloclussion. Then, MP-SN and NSGn angle in each group was measured and $t$ independent test used to analyze data. The result showed that mouth breather group had higher and statistically different mean values of MP-SN angle $(p<0.05)$ and NSGn angle $(p<0.05)$ than nasal breather group. In conclusion, mouth breathing group tends to have clockwise mandible rotation and have vertical growth pattern.
\end{abstract}

Key words: mouth breathing, nasal breathing, vertical growth, vertical skeletal

\begin{abstract}
Abstrak
Pola pernafasan mealui mulut sering dikaitkan dengan pertumbuhan dan perkembangan dentokraniofasial. Perubahan pola pernafasan melalui hidung ke mulut telah dipercaya sebagai salah satur faktor etiologi yang menyebabkan pertumbuhan vertikal wajah yang ekstrim. Tujuan dari penelitian ini adalah untuk melihat perbedaan nilai skeletal dalam arah vertikal antara pola pernafasan normal dan pernafasan melalui mulut pada pasien di klinik ortodonti RSGMP FKG USU tahun 2009-2013. Penelitian ini terdiri dari 44 radiografi sefalometri dari pasien yang berumur 8-12 tahun dengan maloklusi. Selanjutnya, sudut MP-SN dan NSGn pada masing-masing kelompok diukur dan data diolah dan dianalisa menggunakan uji-t independen. Hasil yang didapatkan menunjukkan bahwa kelompok dengan pola pernafasan melalui mulut memiliki sudut MP-SN $(\mathrm{p}<0,05)$ dan NSGn $(\mathrm{p}<0,05)$ yang lebih tinggi dan berbeda secara signifikan dibandingkan dengan kelopmpok dengan pola pernafasan normal. Sebagai kesimpulan, kelompok dengan pola pernafasan melalui mulut memiliki kecenderungan untuk memiliki mandibula yang berotasi searah jarum jam dan memiliki pola pertumbuhan wajah vertikal.
\end{abstract}

Kata kunci: bernapas melalui mulut,bernapas melalui hidung, pertumbuhan vertikal, skeletal vertikal

\section{PENDAHULUAN}

Tujuan utama perawatan ortodonti bagi pasien dengan adanya kelainan dentokraniofasial adalah estetika wajah dan oklusi fungsional yang baik. Kelainan dentokranioafasial disebabkan oleh faktor genetik dan lingkungan. ${ }^{1-3}$ Faktor lingkungan seperti adanya sumbatan saluran nafas yang dapat disebabkan oleh adanya hipertropi kelenjar adenoid dan tonsil, alergi rhinitis, kongenital deformitas nasal, trauma pada nasal, polip, tumor dan faktor predisposisi lainnya dapat menyebabkan seseorang mengubah pola pernafasannya. Perubahan pola pernafasan dari hidung ke mulut dapat mempengaruhi 
perkembangan wajah dan gigi geligi. ${ }^{3-7}$

Sampai saat ini, sudah banyak penelitian yang telah membuktikan bahwa terdapat korelasi bernafas melalui mulut dengan pertumbuhan wajah yang abnormal. Beberapa penelitian mendapati adanya kemiripan dengan karakteristik seperti peningkatan tinggi total wajah anterior yang sering dihubungkan dengan pertumbuhan vertikal dari wajah anterior bawah bersamaan dengan meningkatnya mandibular plane dan sudut gonial yang melaporkan bahwa pola pertumbuhan vertikal wajah yang ekstrim akan menghasilkan Adenoid Face, ${ }^{5,8-9}$

Karakteristik Adenoid Face atau Wajah Adenoid

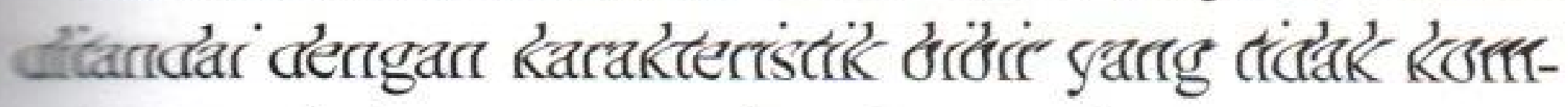
peten, mulut menganga, lengkung rahang yang sempit, retroklinasi gigi insisivus pada mandibula, meningkatnya tinggi wajah anterior, rotasi berbentuk 'V', gigitan silang dan gigitan terbuka anterior. ${ }^{5,10-13}$

\section{BAHAN DAN METODE}

Penelitian ini adalah penelitian deskriptif. Sampel penelitian berjumlah 44 sefalogram dari pasien yang datang ke Klinik Ortodonti RSGMP FKG USU pada tahun 2009-2013. Selanjutnya sampel pe-nelitian dibagi menjadi dua kelompok yaitu kelompok dengan pola pernafasan melalui mulut dan pernafasan normal (hidung) sebagai kelompok kontrol. Pengukuran pharynx atas berdasarkan analisis McNamara serta hasil diagnosis digunakan untuk menentukan pola pernafasan pada setiap sampel.

Seluruh sampel harus memenuhi kriteria inklusi yaitu berumur 8-12 tahun, maloklusi Klas II skeletal yang diukur berdasarkan sudut ANB, foto yang diambil pada NHP dan oklusi sentrik dan pengambilan hasil foto seluruhnya dari Lab Pramita. Kriteria eksklusi adalah pasien yang sudah pernah atau sedang dirawat ortodonti, memiliki kebiasaan buruk lainnya serta sefalogram yang tidak jelas atau sidak dapat dibaca. Penelitian dilakukan setelah mendapatkan persetujuan dari komisi etik USU (Health Research Ethical Committee of North Sumatera).

Prosedur penelitian ini dimulai dengan meletakkan sefalogram lateral beserta kertas asetat di atas pencahayaan tracing box. Selanjutnya sefalogram lineral di tracing dengan pensil $4 \mathrm{H}$ dan dilakukan penentuan titik-titik sefalometri pada jaringan kemas. Adapun titik-titik yang digunakan dalam peneIitian ini yaitu titik, Sella $(\mathrm{S})$, Nasion $(\mathrm{N})$, Gnathion (Gn), Gonion (Go), Menton (Me), Pogonion (Pog) fin Articulare (Ar). ${ }^{4,12,13}$ Setelah menentukan titikdink yang digunakan, selanjutnya dilakukan penarikan garis-garis serta pengukuran sudut-sudut untuk mendapatkan nilai skeletal. Nilai skeletal dalam arah vertikal dalam penelitian ini ditentukan berdasarkan hasil pengukuran sudut-sudut berikut:

MP-SN:Sudut yang terbentuk dari pertemuan garis Sella ke Nasion dan garis bidang mandibular (Gonion-Gnathion). Pengukuran sudut ini untuk mendapatkan relasi mandibula terhadap basis kranium. ${ }^{4}$

NSGn: Sudut yang terbentuk dari perte-muan garis Sella ke Nasion dan garis Sella ke Gnation. Pengukuran sudut ini untuk mendapatkan pola pertumbuhan wajah. ${ }^{4,5}$

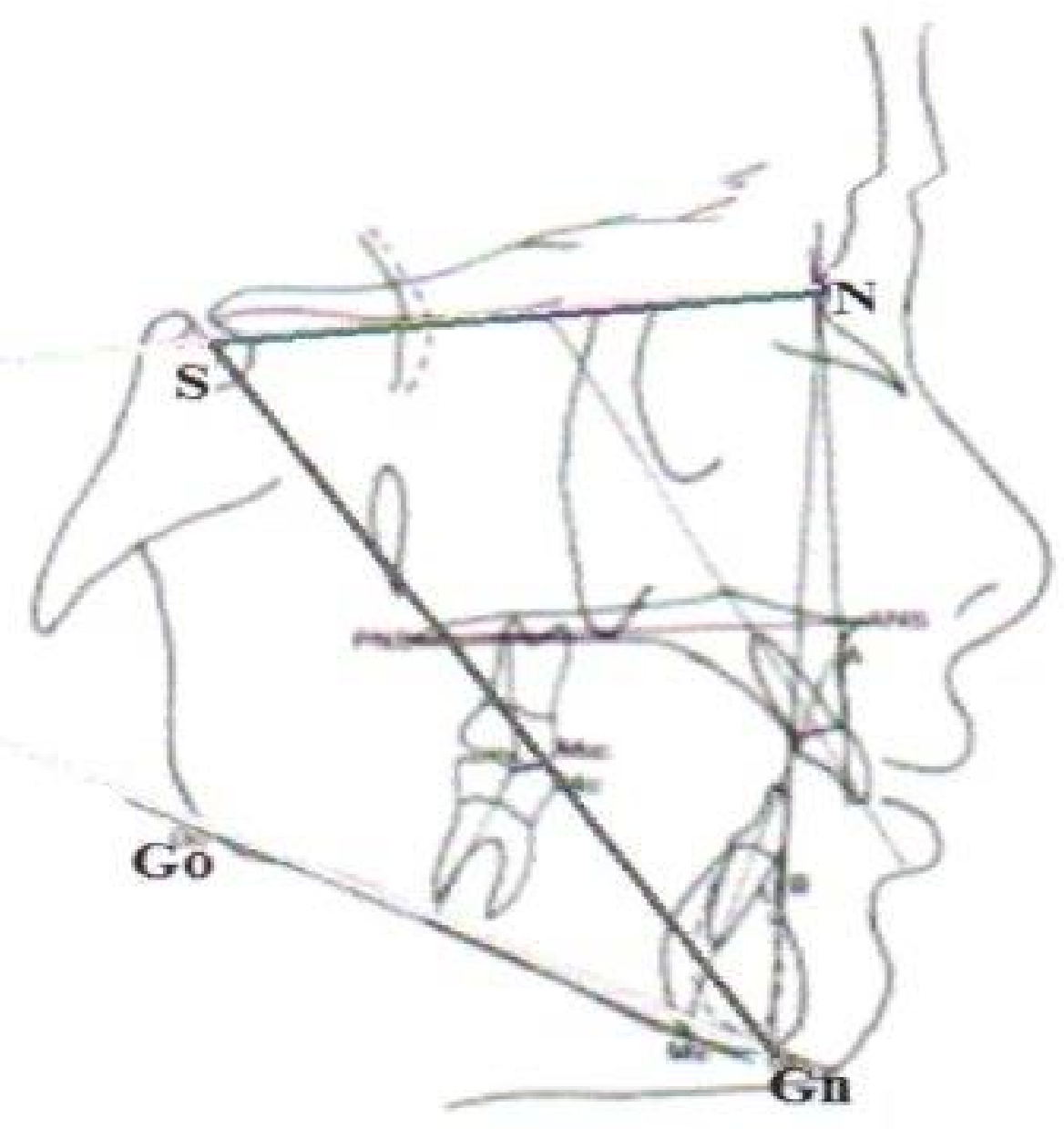

Gambar 1. Sudut MP: SN-kuning, Sudut NSgn-Ungu ${ }^{5}$

Hasil pengukuran nilai rerata sudut pada setiap kelompok diolah dengan menggunakan program perangkat lunak data statistik dan dianalisis dengan uji-t independen.

\section{HASIL}

Hasil analisis menggunakan uji-t independen (Tabel 1) menunjukkan nilai rerata sudut MP-SN pada kelompok dengan pola pernafasan melalui mulut yang lebih besar dan berbeda secara signifikan ( $\mathrm{p}<$ $0,05)$ dibandingkan dengan kelompok pola pernafasan normal (hidung) dengan nilai $\mathrm{p}=0,001$

Tabel 1. Perbedaan nilai rerata derajat sudut MP-SN antara pola pernafasan normal (hidung) dan pernafasan melalui mulut.

\begin{tabular}{|c|c|c|}
\hline $\begin{array}{l}\text { Pernafasan normal } \\
(\mathrm{n}-22)\end{array}$ & $\begin{array}{l}\text { Pernafasan melalui } \\
\text { mulut }(n=22)\end{array}$ & $\mathrm{p}$ \\
\hline $\begin{array}{l}\text { Rerata derajat sudut } \\
\text { MP-SN }\end{array}$ & $\begin{array}{l}\text { Rerata derajat sudut } \\
\text { MP-SN }\end{array}$ & م 0. \\
\hline
\end{tabular}

*signifikan pada $\mathrm{p}<0,05$

Hasil analisis uji-t independen (Tabel 2) menunjukkan nilai rerata sudut NSGn yang lebih besar dan berbeda secara signifikan $(\mathrm{p}<0,05)$ pada kelompok dengan pola pernafasan melalui mulut dibandingkan dengan pola pernafasan normal (hidung) dengan nilai $\mathrm{p}=0,001$. 
Tabel 2. Perbedaan nilai rerata derajat sudut NSGN antara pola pernafasan normal (hidung) dan pernafasan melalui mulut

\begin{tabular}{lll}
\hline $\begin{array}{l}\text { Pernafasan normal } \\
(\mathrm{n}-22)\end{array}$ & $\begin{array}{l}\text { Pernafasan melalui } \\
\text { mulut }(\mathrm{n}=22)\end{array}$ & $\mathrm{p}$ \\
\hline Rerata derajat sudut & $\begin{array}{l}\text { Rerata derajat sudut } \\
\text { NSGN }\end{array}$ & \\
NSGN & $73,614^{\circ} \pm 3,341$ & $0,00^{*}$ \\
\hline $69,705^{\circ} \pm 2,074$ &
\end{tabular}

*signifikan pada $\mathrm{p}<0,05$

\section{PEMBAHASAN}

Kelompok pola pernafasan melalui mulut menunjukkan nilai rerata sudut MP-SN dan NSGn yang lebih besar dan berbeda secara signifikan dibanding dengan kelompok pola pernafasan normal. Hasil ini sejalan dengan hasil penelitian yang dilakukan Lessa $\mathrm{dkk}^{7}$ dan Ucar dkk. ${ }^{14-15}$

Nilai sudut MP-SN yang besar mengindikasikan adanya rotasi mandibula searah jarum jam yang mengarahkan pertumbuhan mandibula ke bawah dan ke belakang. Hal tersebut disebabkan oleh meningkatnya aktivitas di area suprahyoid oleh beberapa otot pada saat bernafas melalui mulut. ${ }^{6} \mathrm{Pe}$ ningkatan otot digastrik anterior dan milohyoid akan menyebabkan depresi mandibula. Jika hal ini terjadi dalam jangka waktu yang lama akan mengakibatkan adanya perubahan arah pertumbuhan rahang. ${ }^{3,15} \mathrm{Se}-$ lain itu, peningkatan aktivitas otot genioglossus akan menyebabkan posisi lidah berada pada inferior dan anterior. ${ }^{10,15}$ Posisi lidah yang berada di posisi anterior dapat menyebabkan mandibula berotasi ke belakang dan ke bawah sehingga dapat menyebabkan tinggi wajah meningkat. ${ }^{6}$ Hal tersebut sejalan dengan hasil yang didapatkan pada pengukuran sudut NSGn.

Nilai sudut NSGn yang besar pada pola pernafasan melalui mulut mengindikasikan posisi mandibula yang berada pada posterior basis kranii dengan pola pertumbuhan vertikal. Hal ini dapat disebabkan karena adanya kecenderungan mandibula yang berotasi searah jarum jam pada kelompok dengan pola pernafasan melalui mulut yang mengarahkan pertumbuhan mandibula ke bawah dan kebelakang yang dapat menyebabkan pola pola pertumbuhan wajah secara vertikal sehingga tinggi wajah meningkat. ${ }^{6,16-18}$

Hasil yang diperoleh pada penelitian ini sejalan dengan tulisan Tourne yang menyebutkan bahwa pola pernafasan melalui mulut diyakini sebagai faktor etiologi yang menyebabkan pola pertumbuhan wajah secara vertikal yang berlebihan. ${ }^{7,8,18}$

Sebagai kesimpulan nilai rerata sudut MP-SN dan NSGn lebih besar pada kelompok pola pernafasan melalui mulut mengindikasikan adanya kecende- rungan terjadinya rotasi mandibula searah jarum jam yang dapat mengakibatkan pola pertumbuhan wajah secara vertikal.

\section{Daftar Pustaka}

1. Budianto E, Purwanegara MK, Siregar E. Karakteristik profil jaringan lunak pada penderita obstruksi saluran napas atas dengan kebiasaan bernafas melalui mulut. Indonesian J Dent. 2008; 15(1): 44-5.

2. Jacobson G, Urtane I, Terauds I. Soft Tissue Profile of children with impaired nasal breathing. Stomatologija, Baltic Dental and Maxilofacial J. 2006; 8(2): 39-42.

3. Suminy D, Zen Y. Hubungan antara maloklusi dengan hambatan saluran pernafasan. M. I. Kedokteran Gigi. 2007; 22(1): 32-9.

4. Singh G. Textbook of orthodontics. $2^{\text {nd }}$ Ed. New Delhi: Jaypee Brothers Medical Publishers, 2007: 94-115,185.

5. Basheer B, Hedge KS, Bhat SS, Umar D, Baroudi $\mathrm{K}$. Influence of mouth breathing on the dentofacial growth of children: a cephalometric study. J Int Oral Health. 2014; 6(6): 50-55.

6. Rettyfina D. Pengaruh pola pernafasan normal dan pernafasan melalui mulut pada maloklusi klas II divisi 1.Tesis. Medan: Program Pendidikan Dokter Gigi Spesialis Ortodonsia FKG USU, 2013:1-10.

7. Lessa FCR. Breathing mode Influence in Craniofacial Development. Rev Bras Otorrinolaringol. 2005; 71(2): 156-60.

8. Frasson JMD, Magnani MBB, Nouer DF, Siqueira CV, Lunardi N. Comparative cephalometric study between nasal and predominantly mouth breathers. Rev Bras Otorrinolaringol. 2006; 72 (1): 72-81.

9. Mckeown P, Mew J. Craniofacial changes and mouth breathing. Irish Dent J. 2011: 1-8.

10. Jordaan R. Postural changes in the craniofacial and craniocervical regions as a result of changed breathing patterns. In: Piekartz H. Craniofacial Pain. German: Elsevier, 2007: 617-30.

11. Rakosi T. An atlas and manual of cepha-lometric radiography. New York: Wolfe. 2007: 62-5,104-5, 130-31.

12. Denotti G, Ventura S, Arena O, For-tini A. Oral breathing: new early treatment protocol. J of Pediatric and Neo-natal Individualized Medicine. 2014; 3(1): 1-3.

13. Moimaz SAS. Longitudinal study of habits leading to malocclusion development in childhood. BMC Oral Health. 2014; 14(96): 1-14.

14. Malhotra S, Pandey RK, Nagar A, Agarwal SP, Gupta VK. The effect of mouth breathing on dentofacial morphology of growing child. $\mathrm{J}$ of Indian. 2012; 1(30): 27-31.

15. Ucar FI, Ekizer A, Uysal T. Comparison of craniofacial morphology, head posture and hyoid bone with different breathing patterns. The Saudi Dent J. 2012; $24: 135-41$.

16. Taner T, Aydinaty BS. Physiologic and dentofacial 
effects of mouth breathing compared to nasal breathing. Text book of nasal physiology and pathophysiology nasal disoreder. Springer Berlin Heidelberg. 2013: 567-588.

17. Souk BQ, Petrus B, Lopes TBJ, Pereira LP, Franco HMG, Becker DO. Mouth breathing children and cephalometric pattern: does the stage of dental development matter? Int J Pediatric Otorhinolaryngol. 2012; 76: 837-8.

18. Bianchini AP, Guedes ZC, Vieira MM. A study on the relationship between mouth breathing and facial morphological pattern. Braz J Otorhino-laryngol. 2007; 73(4): 50-8. 